\title{
Patterns of Use of Social Media in the Culinary Community "Langsungenak"
}

\author{
Zulaikha Zulaikha $^{1}$, Achmad Muzzaki ${ }^{2}$, Jovi Iristian ${ }^{3}$, Meithiana Indrasari ${ }^{4}$ \\ \{zulaikha@unitomo.ac.id ${ }^{1}$, achmad.muzakki@unitomo.ac.id², joviiristian@unitomo.ac.id ${ }^{3}$ \} \\ ${ }^{1,2,3,4}$ Dr. Soetomo University, Indonesia
}

\begin{abstract}
Langsungenak Community is a virtual community created by joining groups on Facebook and WhatsApp, with a focus on culinary attention. They are members of people who like to enjoy food and love cooking, from ordinary housewives to professional chefs. Because it is a virtual community, their interactions are more in the form of writing in chat and discussion about culinary on social media. The diversity of its members who come from regions and professions and different levels of education and backgrounds form their uniqueness in their interactions. Differences also make this community vulnerable to conflict and disputes. But conflicts and disputes can be minimized because the founder of the community applies strict discipline. Interestingly, even though the differences in the area where the residents live gave birth to a difference in time (members came from all over Indonesia to Southeast Asia) but discussions between them could still be done smoothly. Although it has many differences, then they have a pattern in communicating through this social media. This pattern shows how, when, what is done and the delivery of messages while using social media. Broadly speaking, the pattern formed can be used to find out how they use social media itself.
\end{abstract}

Keywords: Patterns, social media, langsungenak

\section{Introduction}

Managing 953,611 members (as of July 9, 201 at 11:25) with different interests and interests is not easy. But Langsunenak managed to prove that their existence as a virtual community that is concerned about culinary, still exists for a period of 3 years, since it was founded on December 8, 2016. In charge of one group on the Facebook platform (as the parent community), 51 WhatsApp groups spread across districts in Indonesia and Hong Kong, and one website, Langsungenak transformed into a virtual community that is active on social media. at the end of 2018).

Langsunenak was originally a virtual community which later morphed into a community in the real world, although it still did not leave the virtual community [1]. By interacting directly, they become more familiar with each other, and that affects their communication on their social media platforms. But not all community members can interact directly in the real world, as many as $81.8 \%$ of respondents in this study stated that they never met face to face and knew first-hand their friends in the community, and only knew him through social media. Therefore, it is interesting to know how their communication patterns are using social media.

Social media has eliminated barriers to distance and time to communicate. Social media then creates its own distance and time through the communication patterns of its users, by using written language, writing methods, punctuation marks, emoticons and gifts contained in its application facilities[2]. These things were then agreed to become a kind of ethics and rules 
of the game in using social media. Of course, there are people who don't understand it, as well as disagreements in face-to-face communication.

In the Langsunenak community, the agreement and understanding were then formalized into group rules, which all members must adhere to. Even the sanctions are very clearly stated in the order if anyone dares to violate them [3].

The patterns of communication through social media are interesting to study because an understanding of these patterns can be used to apply the delivery of business messages through social media to be on target and reach the maximum audience. Lattergrame, a company engaged in the service sector to arrange post schedules on Instagram once conducted research in more than 61 thousand posts to find out when the right time to post so that they could get the maximum response from Instagram users. Based on the results of his analysis, obtained data that the best time to post photos on Instagram is 02.00 in the morning and at 17.00 in the afternoon. According to Matt Smith, founder of Latergramme, that was because at that time many people opened Instagram but only to look around and not upload photos [4].

Different Instagram, different from Facebook. Entrepreneurs in America believe the results of research on the right time to post on Facebook, as follows:

a. The highest 'click' average value occurs from 1:00 to 16:00 every day. According to existing data, the highest peak occurs on Thursday at around 3:00 p.m.

b. The worst time to post something on Facebook is before 8:00 a.m. and after 8:00 p.m. on weekends

c. The addition of photos in the post proved to increase the content of like 'as much as $50 \%$ and increase the number of comments below the post [3].

In the two studies above, data was obtained by looking at posts on the Instagram and Facebook platforms. This paper is based on the results of research with the object under study is the person who posted and the person who gave the comment or affixed 'like.

By knowing the pattern of using social media (Facebook), it is expected to obtain data about the time of posting, the timing of comments and time giving 'like' which is often used by Facebook users. With that knowledge, the use of Facebook for positive things, whether related to business or other positive things can be improved.

\section{Theory}

If previously the theory of use and satisfaction (uses and gratifications) is often used to dissect mass media audiences, this theory is also still properly used to describe social media users. Uses and gratification theory mentions the idea that individual differences cause audiences to search, use and respond to media content differently, which is caused by a variety of different social and psychological factors among individuals in that audience [5]. Most of the research in the area of Uses and Gratifications theory tries to examine what happens behind the use of media by audiences. However, this theory does not pay attention to the direct effect of media on audiences.

There are 5 (five) basic assumptions in the theory of Uses and Gratifications, namely:

a. The audience is active and goal-oriented when using the media

b. Initiatives to get media satisfaction are determined by the audience

c. The media competes with other sources of satisfaction

d. The audience is fully aware of the interests, motives, and use of the media

e. Assessment of media content is determined by the audience

Using the Uses and Gratifications theory to dissect social media users is still quite relevant because, even in social media, audiences are active in seeking, accessing, 
commenting on, debating, liking or disliking and obtaining satisfaction from the use of social media.

Initially, according to Blumler [6] this theory was intended for media research based on media and mass communication. But today, this theory has also been used to examine internet usage [7], cellphones [8], blogs [9], world wide web [10], etc.

Basically, uses and gratifications always bring the latest theoretical approach to the initial stages of each new mass communication media [11]. Thomas Ruggiero [11]formulates 3 characteristics of computer-based communication (internet) that must be examined by researchers based on uses and gratifications, namely:

a. Interactivity. Meaning a condition where individuals in each communication process have control and can change roles in the process (communicator - communicant).

b. Demassification. It is an opportunity for individual media users to choose from a very wide/varied menu. Unlike other traditional media, the internet, in this case, allows each user to adjust the message according to their needs.

c. Asynchronicity. Meaning that messages carried by internet media can connect communicators and communicants at different times, but they can still interact comfortably. An individual can send, receive and store a message at will.

In the case of group members in a virtual community, each member actively searches for information and posts that suit their needs, selectively commenting on posts they like or dislike, have certain motivations when joining a group, and are free to leave unwanted groups and enter the group you like and meet their needs.

\section{Method}

This is quantitative descriptive research, which aims to explain existing phenomena using numbers [12]. This study assesses the nature of the conditions that appear. The purpose of this research is limited to describing the characteristics of something as it is.

The results of quantitative descriptive research are considered important as a precursor study for other studies or further research. As a descriptive quantitative method it has the following characteristics:

a. Tends to use one variable in its operations.

b. Does not rule out the possibility of using two or more variables but not to be linked, compared, or searched for causation.

c. Data analysis is directed at the mean, percentage, or mode search.

d. Data activities are possible to represent.

e. Data analysis is carried out after all data has been collected.

In this study, the researchers distributed questionnaires online to the members of the Langsungenak, in the period of December 2018. From the results of the questionnaire distribution, there were 5,300 members who filled out the questionnaire and sent back to the researchers. The data is then processed, and the numbers will be presented in this paper. 


\section{Result and Discussion}

The results of this study indicate that of the 5,301 respondents with a proportion of $98.8 \%$ women and $1.2 \%$ male, $42.2 \%$ stated that they were not actively posting (both photos and status) in the group, $54.3 \%$ answered sometimes - sometimes posting, and the remaining $3.5 \%$ actively make posts. That means only $3.5 \%$ of members routinely post, and although only occasionally or even inactive make posts, but the members remain in the group.

Among the $96.5 \%$ (a combination of active and sometimes posting), on average they post 1 to 3 times a week $(96.3 \%)$. The remaining $3.7 \%$ post 3 or more on average in one week.

Another activity carried out by group members is to comment on other members' posts. There were $22.8 \%$ of members who often gave comments; some did not give comments $(7.9 \%)$ and those who sometimes gave comments as much as $69.3 \%$. If on average, those who give comment 1-3 times as much as $68.3 \%$, give comments $3-5$ times as much as $19.8 \%$ and give comments 5 times or more as much as $11.9 \%$.

In addition to giving comments, usually group members also often give thumbs up or like, as an expression of like or agree with a post. The average likes and thumbs up are more than 5 times (50.6\%), 3 to 5 times a week as much as $21.6 \%$ and $27.8 \%$ reveals that they only give 1-3 thumbs up or likes time. The results of the study, if depicted in a table, appear as follows:

Table 1. Posts, Comments and Like Members

\begin{tabular}{cccc}
\hline Frequency & Posting $(\%)$ & Comments $(\%)$ & Like / Thumb $(\%)$ \\
\hline $1-3$ & 96,3 & 68,3 & 27,8 \\
$3-5$ & 2,6 & 19,8 & 21,6 \\
$5 \leq$ & 1,1 & 11,9 & 50,6 \\
\hline
\end{tabular}

From the table, it can be seen that people tend to be easier and more often give thumbs up than to comment. Postings once a week are enough, so rarely do posts (both status and photos) more than 3 times a week. While giving comments also the frequency is less, when compared to giving likes or thumbs up.

Regarding the time to take advantage of social media, respondents claimed that every day they took their time specifically to open and read posts in the group Langsungenak (90.9\%). While those who did not spend their time specifically were only $9.1 \%$. While the length of time they open and read the group, is shown in the following table:

Table 2. The average member reads the Group

\begin{tabular}{cc}
\hline Duration & Percentage \\
\hline$\leq 1$ hour & 52,1 \\
$1-2$ hour & 38,3 \\
$2-3$ hour & 5,1 \\
3 hour $\leq$ & 4,5 \\
\hline
\end{tabular}

Usually, they open and read groups in the morning (50.8\%), during the day $(17.9 \%)$, in the afternoon $(2.6 \%)$ and at night $(28.3 \%)$.

If the members make a special time to read the group, of course, there are benefits to the members. The benefits appear in their answers, as follows: 
Table 3. Benefits of groups on social media

\begin{tabular}{lc}
\hline \multicolumn{1}{c}{ Benefits } & Percentage \\
\hline Gaining knowledge about new recipes & 78,7 \\
Gaining knowledge about new culinary entrepreneurship & 52,6 \\
Share knowledge about cuisine & 37,9 \\
Getting new friends & 36,7 \\
Get inspiration for everyday cuisine & 58,2 \\
\hline
\end{tabular}

In group utilization, members are allowed to choose more than one answer provided. The results are almost average. Of the 5 alternative answers, the most chosen ones did get knowledge about new recipes (as many as 78.7\%). But getting knowledge about culinary entrepreneurship and inspiring daily cooking was also chosen by more than half of the respondents. Whereas the benefit of sharing knowledge about cuisine (aspects of selfactualization) is almost the same as the number of getting new friends (both aspects of selfactualization).

\section{Conclusion}

Unlike the research posts on social media that have been done, research with the objects of social media users shows different results. It is known to the community that is a member of the Langsungenak group that giving likes is far more frequent than commenting or posting something in the group. And the special time spent reading more groups in the morning with an average of only one hour.

With data like that, can be used for advertisers and message makers, if you want the posts to be seen by members who are mostly women, and then they can aim at those times. Data about the length of reading which is only one hour can be used to compress messages in such a way that they can be read quickly.

This research is still very likely to be continued in further studies related to advertising, business, and entrepreneurship. The data in this study can be used as a basis for that.

\section{References}

[1] Z. Zulaikha, "Peran Komunitas Maya Dalam Memotivasi Ibu-ibu Untuk Berwirausaha," J. Community Dev. Soc., vol. 1, no. 1, 2019.

[2] N. P. Purtiwi, "Menelusuri Pemetaan Pemasaran Kontekstual," J. Stud. Komun. (Indonesian J. Commun. Stud., 2018.

[3] "No Title.".

[4] E. Rizal, "Inilah waktu yang tepat untuk posting foto di instagram agar memperoleh banyak like," Teknologi.id, 2018. .

[5] A. C. W. Morissan and F. Hamid, "Teori komunikasi massa," Ghalia Indones. Jakarta. Morissan,(2013). Teor. Komun. Individu Hingga Massa. Kencana Prenada Media Group. Jakarta, 2010.

[6] P. E. Pedersen and R. Ling, "Modifying adoption research for mobile Internet service adoption: Cross-disciplinary interactions," in Proceedings of the 36th Annual Hawaii International Conference on System Sciences, HICSS 2003, 2003.

[7] A. J. Flanagin and M. J. Metzger, "Internet use in the contemporary media environment," Hum. Commun. Res., vol. 27, no. 1, pp. 153-181, 2001.

[8] Y. Z. Özcan and A. Koçak, "Research note: A need or a status symbol? Use of cellular telephones in Turkey," Eur. J. Commun., vol. 18, no. 2, pp. 241-254, 2003. 
[9] D. Li, Why do you blog: A uses-and-gratifications inquiry into bloggers' motivations, vol. 17. Marquette University, 2005.

[10] B. K. Kaye and T. J. Johnson, "Online and in the know: Uses and gratifications of the web for political information," J. Broadcast. Electron. Media, vol. 46, no. 1, pp. 54-71, 2002.

[11] S. J. Baran and D. K. Davis, "Mass communication theory: Ferment, and future," Bost. Wardswoth Cengage Learn., 2009.

[12] S. \& Damiyanti, Metode Penelitian. Jakarta, 2011. 